\title{
Cold chain logistics: a possible mode of SARS-CoV-2 transmission?
}

\author{
Yuan-Yuan Li and colleagues argue that the limited evidence supports cold chain logistics as a \\ transmission route for SARS-CoV-2
}

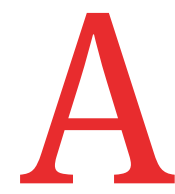

fter the initial wave of the covid-19 epidemic in China was controlled, outbreaks associated with cold chain logistics were reported in several regions that had had no local cases for months. This gave rise to debates about whether SARS-CoV-2 could be transmitted through cold chain transport. Transmission of infection is mainly through droplets when in contact with infected people, but the World Health Organization recognised fomites as a source early in the pandemic. ${ }^{1}$ Although the evidence is not conclusive, we believe the virus could survive long periods in the cold chain.

\section{Reported cases}

The first reported cluster associated with cold chain logistics was an outbreak in Xinfadi market, Beijing's largest wholesale food market, in June 2020, after 56 days without documented local cases. The index case was a 52 year old man with no known exposure to anyone with covid-19. Beijing Centre for Disease Prevention and Control (CDC) performed epidemiological investigations and viral genome analyses and found the SARS-CoV-2 strain in imported frozen salmon was very similar to the strain in the human cases from the market. The CDC speculated that this resurgence might be initiated by transmission from contaminated imported salmon. ${ }^{2}$ A subsequent study using field investigations and onsite simulations at Xinfadi market suggested the virus could spread from contaminated goods to humans, and environmental factors such as low temperature and high humidity, poor ventilation, and insufficient hygiene facilities and disinfection practices might contribute to viral transmission. ${ }^{3}$

A further cluster of cases was reported in July 2020 in Dalian, China, the first of which was in an employee of a cold chain food company. ${ }^{4}$ No local infections had been reported in Dalian for 111 consecutive days before this case was confirmed. Phylogenetic analysis confirmed high homology between the sequences of the virus from the first case and those of samples from the frozen pollock packaging. However, attempts to isolate live SARSCoV-2 failed.

Local outbreaks with cases connected to cold chain logistics were also reported in Kashgar, ${ }^{6}$ Tianjin, ${ }^{7}$ Shanghai, ${ }^{8}$ and Dalian ${ }^{9}$ in China. In all these outbreaks the index case had handled imported frozen products or containers and had had no contact with anyone with covid-19 before their infection was confirmed. Viral nucleic acid was detected on the surfaces of imported food packaging or cargo containers, and the phylogenetic analyses suggested that the virus strains were imported.

Notably, live SARS-CoV-2 virus was isolated from imported food packaging after an outbreak in Qingdao, China. ${ }^{5}$ In September 2020 two stevedores in Qingdao port were identified as having asymptomatic infection during routine nucleic acid screening. Live SARS-CoV-2 virus was isolated from the imported frozen cod packaging they had carried. The genome sequence of the virus isolated from the workers' nasopharyngeal swab was highly homologous to the virus from the frozen cod packaging, suggesting that SARS-CoV-2 could have been transmitted through imported frozen food. ${ }^{5}$

\section{Potential mechanism of transmission}

Is it possible that SARS-CoV-2 could stay alive and infectious during cold chain transportation? Cold chain logistics are used for goods such as temperature sensitive foods and biopharmaceutical products that need to be kept chilled $\left(2^{\circ} \mathrm{C}\right.$ to $8^{\circ} \mathrm{C}$ ) or frozen (below $-18^{\circ} \mathrm{C}$ ) throughout processing, storage, transportation, and distribution. Researchers have studied the persistence of SARS-CoV-2 under different conditions and found it can remain viable for days at relatively low temperatures. At room temperature SARS-CoV- 2 retained its infectivity for three or four days on plastic and stainless steel surfaces, but it can remain infectious for 14 days at $4^{\circ} \mathrm{C} . .^{1011}$ The virus was shown to be more stable and infectious after storage at $-20^{\circ} \mathrm{C}$ than at $4^{\circ} \mathrm{C}$ using low virus concentrations that were close to the actual concentration of viral particles in the environment. ${ }^{12}$ Another study found that the presence of a moderate amount of protein on the surfaces increased the infectivity of SARS-CoV-2. ${ }^{13}$ The authors suggested that a protein rich medium such as airway secretions could protect the virus when it was expelled and might enhance its persistence. $^{13}$

SARS-CoV-2 can reach food products, packaging, or cargo containers if an infected person sneezes or coughs directly on them. The studies described above suggest SARS-CoV-2 could remain alive and infectious during transportation at low temperatures in a closed space without ventilation. Fomite transmission from cold chain to humans could occur if workers who handle the products after transportation do not wear personal protective equipment properly. Workers such as stevedores or wholesalers may be at high risk of SARSCoV-2 exposure because of their direct and frequent contact with transported goods within the cold chain. For consumers, the risk might be lower since the goods are distributed and often kept in environments with adequate ventilation.

\section{Unanswered questions}

The evidence for cold chain transmission remains suggestive not conclusive. Isolation of live virus from cold chain products is rare, occurring only in the Qingdao outbreak. ${ }^{5}$ Although virus strains from cases and cold chain products in the other outbreaks showed high homology, the presence of viral nucleic acid is not a reliable surrogate for the presence of infectious virus. Furthermore, most of the studies investigating the persistence of SARSCoV-2 were conducted under laboratory conditions (controlled relative humidity and temperature), and the initial virus concentrations of the laboratory samples are usually higher than those in droplets in real life situations.

Stable temperature and humidity favour virus survival on surfaces, but the conditions are more variable in real world situations. Attempts to culture SARS- 
CoV-2 from surface swabs taken from an emergency unit and high dependency ward were unsuccessful. ${ }^{14}$ Another study failed to isolate live virus despite ongoing high viral loads of about $10^{5}$ RNA copies/mL of sample. $^{15}$

Despite these uncertainties, we consider it possible that SARS-CoV-2 can survive in the cold chain. Disinfecting surfaces of packages or cargoes in cold chain logistics may therefore be sensible. More research on the frequency of SARS-CoV-2 contamination on food packaging, the association between detection by PCR testing and infectious virus, and SARSCoV-2 viability and infectivity in conditions that simulate those found in cold chain logistics is warranted.

Competing interests: We have read and understood BMJ policy on declaration of interests and have no relevant interests to declare.

This work was supported by the National Natural Science Foundation of China (42077398).

This article is part of a collection proposed by the Peking University Centre for Public Health and Epidemic Preparedness and Response. Open access fees were funded by individual institutions. The BM/ commissioned, peer reviewed, edited, and made the decision to publish. Li-Ming Li advised on commissioning for this collection. Jin-Ling Tang, Di Wang, and Kamran Abbasi were the lead editors for The BMJ.

Yuan-Yuan Li, professor $^{1}$

Hong-Xiu Liu, researcher ${ }^{1}$

Wei Xia, associated professor ${ }^{1,2}$

Gary W K Wong, professor ${ }^{2}$

Shun-Qing Xu, professor $^{1}$

${ }^{1}$ Key Laboratory of Environment and Health, Ministries of Education and Environmental Protection, and State Key Laboratory of Environmental Health (Incubation), School of Public Health, Tongji Medical College, Huazhong
University of Science and Technology, Wuhan, China ${ }^{2}$ Department of Paediatrics, Faculty of Medicine, Chinese University of Hong Kong, Hong Kong SAR, China

Correspondence to: S-QXu xust@hust.edu.cn

\section{(c) $(1) \Theta$ OPEN ACCESS}

This is an Open Access article distributed in accordance with the Creative Commons Attribution Non Commercial (CC BY-NC 4.0) license, which permits others to distribute, remix, adapt, build upon this work non-commercially, and license their derivative works on different terms, provided the original work is properly cited and the use is non-commercial. See: http://creativecommons.org/ licenses/by-nc/4.0/.

\section{Check for updates}

1 World Health Organization. Transmission of SARS-CoV-2: implications for infection prevention precautions. July 2020. https://www.who.int/newsroom/commentaries/detail/transmission-of-sars-cov2-implications-for-infection-prevention-precautions.

2 Pang X, Ren L, Wu S, et al, COVID-19 Field Response Group, COVID-19 Laboratory Testing Group. Cold-chain food contamination as the possible origin of COVID-19 resurgence in Beijing. Natl Sci Rev 2020;7:1861-4. doi:10.1093/nsr/nwaa264

3 Li X, Wang Q, Ding P, et al. Risk factors and on-site simulation of environmental transmission of SARS-CoV-2 in the largest wholesale market of Beijing, China. Sci Total Environ 2021;778:146040. doi:10.1016/j.scitotenv.2021.146040

4 Ma H, Zhang J, Wang J, et al. Covid-19 outbreak caused by contaminated packaging of imported coldchain products - Liaoning Province, China, July 2020 China CDC Wkly 2021;3:441-7. doi:10.46234/ ccdcw2021.114

5 Liu P, Yang M, Zhao X, et al. Cold-chain transportation in the frozen food industry may have caused a recurrence of COVID-19 cases in destination: Successful isolation of SARS-CoV-2 virus from the imported frozen cod package surface. Biosaf Health 2020;2:199-201. doi:10.1016/j. bsheal.2020.11.003
6 The source of the epidemic in Kashgar, Xinjiang has been found: it is a container. Voice of China 2020 Nov 27. http://china.cnr.cn/yaowen/20201127/ t20201127 525344096.shtml.

7 Yang S, et al, Covid Field Response Group, Laboratory Testing Group. A case of covid-19-Tianjin Municipality, China, November 7, 2020. China CDC Wkly 2020;2:884-5. doi:10.46234/ccdcw2020.241

8 Fang F, Song Y, Hao L, Nie K, Sun X. A case of covid-19 detected in a cargo worker at Pudong Airport - Shanghai Municipality, China, November 8, 2020. China CDC Wkly 2020;2:910-1. doi:10.46234/ccdcw2020.246

9 COVID cases in Dalian traced to cold-chain cargo. China Daily 2021 Jan 3. https://www.dl.gov.cn/ art/2021/1/11/art_460_512000.html

10 Chin AWH, Chu JTS, Perera MRA, et al. Stability of SARS-CoV-2 in different environmental conditions. Lancet Microbe 2020;1:e10. doi:10.1016/S26665247(20)30003-3

11 van Doremalen N, Bushmaker T, Morris DH, et al. Aerosol and surface stability of SARSCoV-2 as compared with SARS-CoV-1. N Engl J Med 2020;382:1564-7. doi:10.1056/ NEIMc2004973

12 Huang SY, Kung YA, Huang PN, et al. Stability of SARS CoV-2 spike G614 variant surpasses that of the D614 variant after cold storage. mSphere 2021;6:e0010421. doi:10.1128/mSphere.00104-21

13 Pastorino B, Touret F, Gilles M, de Lamballerie X, Charrel RN. Prolonged infectivity of SARS-CoV-2 in fomites. Emerg Infect Dis 2020;26:2256-7. doi:10.3201/eid2609.201788

14 Colaneri M, Seminari E, Novati S, et al, COVID19 IRCCS San Matteo Pavia Task Force. Severe acute respiratory syndrome coronavirus 2 RNA contamination of inanimate surfaces and virus viability in a health care emergency unit. Clin Microbiol Infect 2020;26:1094.e1-5. doi:10.1016/j. cmi.2020.05.009

15 La Scola B, Le Bideau M, Andreani J, et al. Viral RNA load as determined by cell culture as a management tool for discharge of SARS-CoV-2 patients from infectious disease wards. Eur J Clin Microbiol Infect Dis 2020;39:1059-61. doi:10.1007/s10096-02003913-9

Cite this as: $B M / 2021 ; 375: \mathrm{e} 066129$

http://dx.doi.org/10.1136/bmj-2021-066129 